\title{
The Role of the Punjab Education Foundation Pakistan in Teachers' Training in Private Sector Schools under Public-Private Partnership
}

\author{
Muhammad Javed \\ Doctoral Candidate; School of Educational Studies, Universiti Sains Malaysia, \\ 11800 USM Pulau Pinang, Malaysia \\ Email:mjaved_iub@yahoo.com \\ Lin Siew Eng, PhD \\ Senior Lecturer; School of Educational Studies, Universiti Sains Malaysia, \\ E-mail: selin@usm.my \\ Abdul Rashid Mohamed, PhD \\ Dean School of Educational Studies, Universiti Sains Malaysia, \\ E-mail: rich@usm.my \\ Irem Mushtaq \\ Doctoral Candidate, School of Educational Studies, Universiti Sains Malaysia \\ 11800 USM Pulau Pinang, Malaysia \\ E-mail: Irem_atif@yahoo.com \\ Noor Hashimah Hashim: PhD \\ Prof.School of Educational Studies, Universiti Sains Malaysia \\ 11800 Pulau Pinang, Malaysia \\ E-mail: shimah@usm.my
}

Accepted: April 24, 2012 Published: May 27, 2012

Doi:10.5296/ijld.v2i3.1709 URL: http://dx.doi.org/10.5296/ijld.v2i3.1709

\begin{abstract}
An enormous number of problems including scarce financial support, dearth of proficient teachers, outdated curriculum, non-professional approach of stakeholders, lack of facilities, inadequate sources and unorganized programs for Teachers' Training are impediments in the quality of school education in Pakistan. The teachers in private schools require an organized and well managed system of Teachers' Training to impart the innovative pedagogical, andragogical, and professional skills and strategies for the improvement of teaching methodologies.

The Punjab Education Foundation (PEF) Pakistan has taken initiative for Teachers' Training for private sector schools under public private partnership scheme. PEF is playing its
\end{abstract}


pivotal role in imparting education and Teachers' Training Programs through Cluster Based Training (CBT), School Leadership Development Program (SLDP) and Teaching in Clusters by Subject Specialists (TICSS). Drawing upon the basic concepts, procedures and philosophy of Teachers' Training, this paper describes the role and achievements of Punjab Education Foundation regarding Teachers' Training in the province Punjab, Pakistan. Through documentary analysis, the parameters and mechanism adopted by PEF regarding Teachers' Training has been examined. Some measures for promoting the quality of teaching through Teachers' Training at the private sector schools of the country have also been proposed.

Key Words: Teachers' Training Philosophy, Pedagogical, Professional Skills, Punjab Education Foundation, Role, Achievements, Mechanism, Measures.

\section{Introduction}

Education is the revolutionary force for development and progress of any nation. The multifarious impacts of education on every aspect of human existence have become indispensable for policy framework especially for developing countries (Saphier \& Gower, 1997).

Education is envisaged as an influential instrument in bringing about the desired changes in the social and cultural life of a nation. The whole set up of education is formed by the teachers, who play a pivotal role in the system of education. The teaching profession needs, of course, development of adequate pedagogical skills, dedication to teaching and a commitment for continuous growth and learning (Chism, 1998).

In this perspective the painstaking efforts are required to equip the teachers not only with pedagogical skills but also try to promote the positive professional attitude in them. The competent, professionally trained and enthusiastic teachers are required to teach at every level (Brookfield, 2006). Therefore, a little effort has been made to investigate that to what extent different teacher training programs are successful in developing positive professional attitude of the teachers.

A good teacher is expected to be committed to his work, would have the ability to take the initiative (Wilson, 1969). Saphier and Gower (1997b) have claimed that teacher's personality in the attitudinal sense is a significant factor in teacher's behaviour and it has great impact on student's achievement. The teacher as a professional must know the art of communication, understanding others and ability to learn from the experiences. They should be able to facilitate learning effectively (Saphier \& Gower, 1997a).

Robertson (1996) stated that the teachers who posses professional and interpersonal skills are more effective in their classrooms in terms of behaviour, attitude and achievement. Prince (2002) described that professional attitude serves in many valuable ways and knowing these attitudes can also serve a lot.

The Improvement of the profession of education lies in the hands of teacher education (Shah, 2003). The enhancement of positive professional attitude of teachers not only promotes the teachers' efficiency but also helps in making the school attractive for students and teachers.

The effectiveness of teacher in the classroom depends on the effectiveness of teacher training. To evaluate the effectiveness of instruction one must look into what is happening in the classroom 
and most of all the attitude of the teacher in the teaching Learning situation. The performance of a teacher in this process is related to set of knowledge and abilities, which he possesses. For teaching learning process to be effective, a sound professional education and training is inevitable (Darling-Hammond, 2003).

Teacher training, therefore, is a specialized and significant segment of education entailing systematic preparation for the development of teaching skills among those who may be attracted towards teaching profession. The teacher training should be imparted so effectively using new methods and techniques that the student teacher may be able to perform in a better way in the practical situation (Berry, 2001). Sargent (2003) criticized the present system of teacher training for its failure to arouse delight in students in what they do. Memon (2007) complained against teachers for ignoring the teaching practices long known to be desired. The teacher training programs in Pakistan also have been continuously the objects of dissatisfaction. It is always blamed that our teachers are not performing their duties and responsibilities adequately and satisfactorily. The government must provide affordable education and training opportunities.

Therefore, a little effort has been made to measure the effectiveness of teachers' training programs in developing professional attitude of teachers organized by the Punjab Education Foundation in the province Punjab, Pakistan.

\section{Significance of the Study}

This study will provide guidelines to increase the professional efficiency of teachers. It will enable the teachers to focus their attention and direct their efforts on developing such skills and attitudes among the teachers as needed for the schools of Pakistan. This study will provide feedback for the PEF in framing suitable mechanism for teachers' training programs. This study may assist the institutions lagging behind in developing professional attitude and other weak areas. This study may provide bases for further research also.

\section{Objectives of the Study}

The objectives of study were:

1) To find out the role of PEF in developing the professional attitude of teachers through various teachers' training programs.

2) To assess the effectiveness of teachers' training module in developing professional attitude of teachers.

3) To suggest suitable measures for PEF to improve teachers' training in the Punjab.

4) This study may be helpful for policy makers, administrators and teachers to improve the teachers' training programs. It may also be helpful for the teachers as well as working teachers in developing positive attitude toward teaching profession.

\section{Review of the Related Literature}

Nunan (1991) elaborated that teachers' training equips the teachers with a collection of skills, abilities, attitude, knowledge and other behaviours that help him/her in becoming a better teacher. According to the opinion Joyce and Weil (1986), the teachers' training program should:

- Create competency amongst trainees to teach subjects of specialization on the bases of accepted principle of teaching in context of the implemented school curriculum. 
- Develop understanding, interest and attitudes, which would enable him to foster all round personality development of the students and develop skills in identifying, selecting, innovating, and organizing learning experiences for teaching.

- Develop perception of the psychological principles of development, cognitive, psychomotor and attitudinal learning (Tennant \& Pogson, 1995).

- Develop skills of guidance and counseling for the solution of students' personal as well as academic problems.

- Identify the role of parents, peer group and the community in developing the students' personality and harmony between home-school relationships (Knowles, 1984).

Objectives of the teachers' training developed by Stone, Horejs, and Lomas (1997) on the basis of survey of training institution in England, Wales and Northern Ireland are:

- To provide opportunities for teachers to acquire and improve teaching skills.

- To enable the teachers to prepare lesson plans effectively.

- To help the students to develop desirable traits, attitudes and abilities.

- To enable the students to acquire the characteristics of a teacher and to display appropriate behaviour.

Proponents of effective teacher education suggest that the vast majority of teacher training programmes focus solely on the development of teacher's knowledge, teaching skills, or both. Two questions can be raised concerning the effectiveness of effective Teachers' Training programs; first to what extent do teachers acquire the appropriate interpersonal skills as the result of participating in teachers' training program? Second to what extent are the teachers who participate in such programs more effective in their classrooms than those teachers who do not participate in these programs (Hussain, 2004)? Teachers are a key enabling factor in improving the quality of education. The evidence is that teachers are critical to any reforms designed to improve quality" (Govt. of Pakistan; 2005)

\section{Perspectives and Importance of Teachers' Training in the Light of Educational Policies (1947 to 2009)}

The First Educational Conference1947 resolved that teachers' training is of vital significance. Provincial and central government should provide the funding. It promised regular training for schoolteachers. The policy also announced to establish first rate Teachers Training Institutes for Women, which would train them for nursery \& primary classes (Govt. of Pakistan, 1947). The Second Educational Conference 1951 recognized to raise the status of the teachers. It proposed to establish 101 training institutions for primary school teachers (male \& female) and 26 such institutions for secondary school teachers (Govt. of Pakistan, 1951).

The National Education Commission 1959, instead of focusing on teachers' training, stared with the assumption that schoolteachers have too many free days and that need to be regulated and monitored (Govt. of Pakistan, 1959).

The Commission on Students' Problems and Welfare 1966 did not come up with any specific proposal to improve the quality of teacher through teachers' training (Govt. of Pakistan, 1966). The 1969 policy proposed that Separate Directorates, as autonomous governing bodies be created headed by Director General, for recruitment and training of teachers at all levels (Govt. of Pakistan, 1969-70). 
The Education Policy 1972 assured to improve schoolteachers' training structure. Their recruitment $\&$ training should be on the pattern of Central Superior Service (CSS) of Public Service Commission of Pakistan. The policy led to the creation of Academy of Educational Planning \& Management to accomplish it. The policy also proposed that 2 members of the Public Service Commission of Pakistan be recruited from the education cadre. District Education Councils were to expedite the recruitment, training and promotions of the schoolteachers (Govt. of Pakistan, 1972).

Compared to the previous policies on teachers' training, the National Education Policy and Implementation Program 1979 was clear, categorical and emphatic. It promised to launch a massive ideological reorientation training program for the teachers and proposed to upgrade all existing Elementary Training Institutions to Colleges of Elementary Teachers. Like the 1972 policy it proposed the establishment of Academy of Educational Management and Planning for in-service teachers training (Govt. of Pakistan, 1979).

The National Education Policy 1992 proposed to enhance the teachers' training curricula. This policy also proposed for strengthening the Academy of Educational Planning and Management and creating such Academies in the provinces. It promised to increase the financial autonomy $\&$ authority of District Education Officers to streamline the recruitment training of school teachers (Govt. of Pakistan, 1992).

The National Education Policy 1998-2010 continued emphasis on re-orientation of teachers' training program. It proposed that an Education Public Service Commission would be established for the recruitment of teachers. It also proposed the establishment of a new National Institute of Teachers Education (NITE), which would train and improve the skills of over 300 teachers annually. It also called for the setting up of Teachers Foundation, which will cater for the needs of teachers, and national teachers' conferences would be organized. The Academy of Educational Planning and Management will offer short \& long term courses to improve the professional skills of the teachers (Govt. of Pakistan, 1998-2010).

One of the objectives of National Education Policy 2009 is to enable Pakistan to fulfill its commitments to achieve Dakar Framework of Action, Education For All (O’Sullivan, 2005) goals and Millennium Development Goals (MDGs) relating to education (Govt. of Pakistan, 2009).

\section{The Role and Contribution of the Punjab Education Department}

Teachers' Training is a vehicle of development. A powerful correlation exists between education and attainment of the goals set out in the United Nations Millennium Declaration of Sept. 2000. Therefore, efforts aimed at achieving the Millenniums Development Goals (MDGs) and Education For All (EFA) goals must ensure that education is integrated within broad framework of national economic and social policy (Ungurean, 2005).

The Government of Pakistan has expressed a strong commitment toward achieving MDGs and EFA goals reflecting its measures to improve education in not only the education sector reforms for 2001-2004 but also through the National Education Policy (1998-2010), The Ten Years Perspective Development Plan (PDP) (2001-2011) and the National Plan of Action for 
Education for All 2000-2015. These focus on several issues notably Universal Primary Education, Improved Literacy Rate, and Higher Quality Education through Teachers Training. Pakistan is facing enormous hurdles like widespread poverty, gender disparities, lack of facilities, inadequate opportunities for education and severe budgetary constraints in meeting education needs (Kabeer, 2003).

The Government is committed to achieve of education related Millennium Development Goals (MDGs) by 2015. The primary focus is on provision of quality education through teachers' training in the Province of the Punjab. The allocation for Education Sector for the financial year 2010-11 is pitched at Rs. 23,300 million which is higher than the last year's provision (Government of the Punjab, 2010).

Table.No.1.1

Outcome Based Target

\begin{tabular}{lllllll} 
Program & $\begin{array}{l}\text { Targets, } \\
\mathbf{0 9 - 1 0}\end{array}$ & Achievements, 09-10 & Targets & & \\
\cline { 7 - 7 } & $\begin{array}{l}\text { Training of Teachers } \\
\text { and Managers }\end{array}$ & 122,087 & 120,000 & 150,000 & 175,000 & 200,000 \\
\hline
\end{tabular}

Source: (Government of the Punjab white Paper Budget 2010-11, Medium Term Development Framework (MTDF) 2010-13 and Development Program 2010-11, p-53)

Table.No.1.2

\section{Budget Allocation}

Particulars Of The Scheme

Budget Estimates 2009-10

\begin{tabular}{ll}
\hline Punjab Education Foundation & Rs: 4,000,000,000 (400o Millions) \\
& Rs: 4,000,000,000 (4ooo Millions) Revised \\
Total Public Private Partnership & Estimates 2009-10 \\
& Rs: 4,000,000,000 (4ooo Millions) Revised \\
Integrated Education Learning Programs & Estimates 2009-10 \\
\hline
\end{tabular}

Source: Government of The Punjab, Estimates of Charged Expenditure and Demands for Grants (Current Expenditure) Vol-I (Fund. No. Pc 21001 - Pc21015) For 2010 - 2011, p-1127

\section{Millennium Development Goals (MDGs)}

The Millennium Declaration namely 'Millennium Development Goals' was signed in Sep, 2000 in New York. This Millennium Declaration was a milestone in international cooperation, inspiring development efforts that have improved the lives of hundreds of millions of people around the world. The world leaders will gather again at the United Nations in New York in 2015 to review progress, assess obstacles and gaps and agree on concrete strategies and actions to meet the EIGHT Millennium Development Goals by 2015. No doubt MDGs provided targets, but national development strategies require experience and policy coherence key (Littlefield, Morduch, \& Hashemi, 2003). Akiyama (2005) stated that the Achievement of universal primary education with quality is one of the Millennium goals. Ki-Moon (2007) the secretary general of UNO declared that The Millennium Declaration represents the most 
important promise ever made to the world's most vulnerable people. The Millennium Development Goals summit will be an opportunity for world leaders to translate this evidence into a concrete agenda for the social, economic and educational development.

The government has taken several strong initiatives like Education Sector Reform Action Plan 2001-2005 to improve and refurbish the existing system of education in Pakistan. The government has planned to increase the budget for education by 6\% of GDP till 2015 (Govt. of Pakistan, 2007a).

\section{Strengthening of Teachers' Training}

The government has taken several substantial initiatives for teachers' education and professional development. During fiscal year 2007-2008, more than 20,660 elementary school teachers have been trained in the country costing Rs. 135 million (Govt. of Pakistan, 2007b).

For promoting Public-Private-Partnership in the education sector, particularly in the case of disadvantaged children, a specific percentage of the education budget as grant in aid (to be decided by each Province) is allocated to philanthropic, non-profit educational institutions (Govt. of Pakistan; 2005).

\section{Improving Teachers' Quality}

The reform of teaching quality is of the highest priority. There is a consensus amongst all stakeholders that the quality of teachers is unsatisfactory. The growth of private sector is adding new complexities to the teaching profession and needs to be taken into account in any reform of the system. Teachers' training arrangements, for professional development, accreditation and certification procedures shall be standardized and institutionalized. International Agencies like United Nations Educational, Scientific and Cultural Organization (UNESCO) and Organization for Economic Co-operation and Development (OECD) etc are also urging governments to establish reliable information gathering and dissemination systems for comparisons, analysis and monitoring the progress on various international goals like the EFA and MDG's (Govt. of Pakistan 2000).

\section{Role of the Private Sector in Education and Public-Private Partnership}

The existence of private schools is quite a significant phenomenon in Pakistan and the role of the private sector is usually well understood and defined in a policy making. The public-private partnership is also being encouraged nowadays. In recent years, public-private partnerships, in other countries, especially in the education sector like the Global Education Initiative (GEI) in Jordan which has been successfully replicated in India, Egypt and Palestine. In 2007, the World Economic Forums, GEI and UNESCO launched a new program under the title of Partnerships for Education (PFE).

This shows that public-private partnership is a global agenda and a developing country like Pakistan can really benefit from the resources of the international community in initiating a comprehensive partnership. Any education system needs to ensure quality, capacity and career growth. The most important input into teaching quality is teachers' training. Ideally a good 
training system imparts a set of skills that include matters like good pedagogical skills, ability to assess the students' performance.

Two prime problems of Pakistani education system are as 1) the inability of the system to attract and/or retain quality human resource to teaching and 2) good quality teachers' training. As regards the province of the Punjab, the task of in-service training in public sector is handled by the Department for Staff Development. In service training is an extremely difficult task due to the large number of teachers (approx 01 million) and deficiencies in coordination. On the other hand Punjab Education Foundation is functioning in private sector for the provision of education and teachers' training (Govt. of Pakistan; 2006)

\section{Punjab Education Foundation; Brief History}

The Punjab Education Foundation was established as an autonomous statutory body in 1991 to encourage and provide education to the poor in the private sector operating on non-commercial/non-profit basis through public private partnership. The rules of Punjab Education Foundation were restructured under the PEF Act-XII of 2004 and 2005 available at. http:// www .pef. edu.pk/about-pef-history.html.

\section{Punjab Education Foundation Vision}

The vision of PEF is to promote quality education through Public Private Partnership, encourage and support the efforts of private sector through technical and financial assistance, innovate and develop new instruments to educational opportunities at affordable cost to the poor. http://www.pef.edu.pk/about-pef-mission.html

\section{Punjab Education Foundation Functions}

The core functions of the Foundation are to:-

1. Assist educational institutions in capacity building, including training of teachers.

2. Provide financial assistance for the establishment, expansion, improvement, and management of educational institutions and allied projects.

3. Provide incentives to students, teachers, and educational institutions.

4. Promote public-private partnerships relating to education.

5. Provide technical assistance to educational institutions for testing policy interventions and innovative programs for replication.

6. Rank private educational institutions based on educational standards.

7. Raise funds through donations, grants, contributions and subscriptions etc.

8. Undertake any other function as may be assigned to it by the Board with the approval of the Government.

\section{The Role of PEF}

The role of PEF is multifarious; it provides free education to the less privileged areas, arrange quality training for the teachers and the school administrators besides providing educational vouchers for the child laborers and out of school children, who otherwise, have no other opportunity to get education. 
The provision of free education is the most fundamental human right of every child and the Punjab Education Foundation is committed to fulfill its obligation of providing free education to the children to their doorsteps. It is helping to build sustainable partnerships with individuals and communities at large for optimum results. Recently World Bank has termed the PEF as a role model project in education sector for the third world countries and it has expressed its full satisfaction of the agenda of promoting Quality Education.

It is providing free education to about 8 lac children with an amount of Rs. 5 billion. This project is an important step towards achieving Millennium Development Goals.

\section{The Continuous Professional Development Program}

The Continuous Professional Development Program (CPDP) aim to improve the mentoring capabilities of professional teachers. It is enhancing the pedagogical skills of the teachers through Cluster Based Training (CBT) Program. The basic purpose of CBT is to prepare teachers for teaching profession. The poor educational learning outcomes of students have become a matter of great concern for parents, public and private sector managers of education. The incompetent human capital in education sector is a major constrain in the achievement of excellence in the field of quality education. The PEF is fully cognizant of the view that the objectives of Cluster Based Training (CBT) in the province can best be achieved in Public Private Partnership.

The sever lack of qualified manpower in teaching profession at school level has impeded the national strategies and mechanism for quality education and the profound desires of the stakeholders.

At the moment, approximately, 40\% educational institutions in urban areas and more than $30 \%$ in rural areas in the province of the Punjab are being run and managed in the private sector. The private educational institutions have a vast and varied range, starting from the elite school systems, to average schools and low-cost private educational institutions. The low-cost educational institutions not only lack proper physical infrastructure but are also deficient in human capital in the shape of qualified teachers.

\section{The Academic Development Unit (ADU)}

To achieve the objectives, PEF has established an Academic Development Unit (ADU) which has recruited a core team of 5 subject specialists (i.e., English, Mathematics, Biology, Physics and Chemistry).

\section{Professional Requirements and Evaluation for the Subject Specialists}

Energetic subject specialists with excellent academic record, outstanding pedagogical skills , communicational \& dissemination expertise, sound didactic resource base of knowledge, analogical deductive assimilation in the relevant discipline, adequate experience in teachers' training, mentoring and conducting workshops experience, well conversant in the use of computer and application of audio-visual aids for lecture/training purposes have been selected on the recommendations of constituted panel of scholars of erudition and impeccable credentials after scheduled procedure of test/interview. The performance of subject specialist is 
continuously evaluated by the Quality Monitoring Triangle (QMT) i.e. School Management, PEF and Third Party Validation (TPV).

\section{Orientation of the Subject Specialists}

To extract quality outcome from the ADU team, each subject specialist is given an intensive briefing on their roles and responsibilities to strengthen their training skills through a six-day extensive training mainly focusing the concepts like pedagogy, andragogy, learning theories, Bloom's Taxonomy, construction of specific objectives, lesson planning, direct instructions, effective communication skills (verbal and non verbal) classroom management, Piaget's theory of cognitive development, time management and assessment of training needs in context of CBT environment.

The subject specialists are playing a key role in supporting, guiding and teaching in the private educational institutions. They identify the training needs of the cluster schools by carrying out the Training Need Analysis (TNA) for core content subject knowledge of the teachers/students and recognize these needs for consideration to rectify such needs accordingly.

They have to ensure that there is a sustained improvement in the subject knowledge, understanding and pedagogical skills in relation to the prior level of attainment before the PEF intervention. The PEF pre-launching entry test of the class serves as a bench mark to assess the contribution of the subject specialists. The subject specialists contribute to the maintenance of conducive and purposeful congenial learning and knowledge dissemination environment. They teach in the cluster of schools in core content subject knowledge i.e. English, Mathematics, Physics, Chemistry and Biology. They also design tests for the assessment and examination of the Foundation Assisted Schools (FAS) and carry out tours to ensure the accuracy of information in terms of enrollment in the Foundation Assisted Schools. They also serve as a part of assessment and examination teams constituted by the Punjab Education Foundation. They liaise with the other leading experts engaged in teachers' training and professional development in public and private sector and share experiences for the promotion of education in private sector. They develop a resource base for pedagogy, andragogy and subject knowledge in PEF for the benefit of teachers of the private educational institutions. They teach in the cluster of schools in less affluent and marginalized urban and rural areas. In addition to classroom teaching, they also interact with peers and associates for improving their didactic resource base and content knowledge.

\section{Cluster Based Training (CBT) in Public Private Partnership}

The teachers of 7-10 private schools falling in close proximity making a group of 35-50 participants having similar training needs, though diversified educational background are provided training at a venue for conducting training. The CBT is being conducted mainly on the content knowledge of English, Mathematics, Science, Physics, Chemistry and Biology. The primary thrust is in urban, semi-urban and rural areas of the province. In addition, a few sessions are also held to meet the training needs related to classroom management, teaching slow learners, lesson planning, group work, use of AV aids, joyful and activity based teaching etc. 


\section{The Rationale and Basic Objectives of CBTs}

The basic objectives of Cluster Based Trainings are to:

1. Create a richer learning environment.

2. Introduce newer educational methods and offer teachers in these schools a chance to share the most innovative ideas and concepts being explored in modern era.

3. Make their teaching/training methodology more effective.

4. Provide more shareable resources for the heads and teachers of cluster schools in remote areas where these activities cannot be provided easily in their own schools.

5. Overcome isolation by making training accessible to more teachers at one focal point which is more advantageous. By executing this, the worth of working together and sharing the feedback builds supportive network.

\section{Output of CBT}

The teachers feel more confident in using materials and as a result their teaching/ training methodology improves which makes lessons and learning more effective. Teachers develop pedagogical skills through participation in the program in schools. The indirect beneficiaries are peers and families of those who participate in the program.

\section{Salient Features of CBT}

Any private (Primary, Elementary or Secondary) school willing for partnership with less than Rs.400 fee structure is included for CBTs. The participant teachers attending the workshop receive a financial incentive of Rs.100 per day, reasonable refreshment and certificates. The trainee teachers, in CBT, are included according to 3 categories namely; 1-5 teachers from primary, 6-8 teachers from elementary and 9-10 teachers from secondary schools respectively. Schedule of CBTs

Based upon all the observations, CBT is conducted at primary level by mixing 2-3 subjects i.e., English, Mathematics and Science. While for higher level the effort is to mix only 2 subjects per 6 day training session. Learning from its experience of initial workshops, PEF standardized its schedule in terms of at least 4 hours per day and at least 6 days for 01 CBT.

Before the start of CBT, the leading entrepreneurs and the managers of the private educational institutions are consulted to explore the possibility of teachers' training by the PEF in Public Private Partnership and the consequent quantifiable impact assessment in terms of quality education on the learning outcomes of the students, being the ultimate beneficiaries. The gists of observations and field survey have been very encouraging for forging Public Private Partnership.

The private educational institutions are enthusiastic to constitute a cluster for CBT for the teachers' training through Public Private Partnership and willing to share their available resources in terms of infrastructure, laboratories, teaching and ancillary staff etc. for the Cluster Based Training (CBT) and professional development.

\section{Monitoring \& Evaluation}

Continuous monitoring and evaluation of CBTs are integral parts of the system for consistent improvement. ADU adopts strategy to ensure proper monitoring and subsequent evaluation for this purpose. The representative of ADU observes each CBT and compares the Pre and Post 
test results of participants to prepare reports about each individual workshop by describing future course of action and shares each workshop's report with Board members and PEF's Senior Management for further improvement.

Table.No.1.3

Contribution of Punjab Education Foundation (from 2002 to 2010)

\begin{tabular}{|c|c|c|}
\hline S.No & Specifications & Strength \\
\hline 1 & $\begin{array}{l}\text { Total Schools Funded by PEF under Public-Private } \\
\text { Partnership (PPP) }\end{array}$ & 1771 Schools \\
\hline 2 & $\begin{array}{l}\text { Total Students benefited from Financially Assisted } \\
\text { Schools (FAS) }\end{array}$ & $\begin{array}{l}\text { More than } 8 \\
\text { lac }\end{array}$ \\
\hline 3 & $\begin{array}{l}\text { Total Organizations involved in CBTs for Teachers' } \\
\text { Training }\end{array}$ & 27 \\
\hline 4 & $\begin{array}{l}\text { Total Organizations involved in SLDPs for } \\
\text { heads'/Principals' Training }\end{array}$ & 25 \\
\hline 5 & Total CBTs Workshops Conducted & 1770 \\
\hline 6 & Total Teachers Trained through CBTs & $\begin{array}{l}\text { More than } \\
70000\end{array}$ \\
\hline 7 & Total SLDP Workshops Conducted & 454 \\
\hline 8 & Total Heads/principals Trained through SLDPs & $\begin{array}{l}\text { More } \\
8000\end{array}$ \\
\hline 9 & Total Resource Persons for CBTs & 276 \\
\hline 10 & Total Resource Persons for SLDBs & 93 \\
\hline 11 & $\begin{array}{l}\text { Total Teachers Trained by PEF through CBTs and } \\
\text { SLDPs }\end{array}$ & 78000 \\
\hline 12 & $\begin{array}{l}\text { Training Cost per workshop/teacher } \\
\text { PEF's planning to take over Non Functional }\end{array}$ & $\begin{array}{l}\text { Rs. } 2,828.13 \\
1006\end{array}$ \\
\hline 13 & Schools of the Govt. of the Punjab & \\
\hline
\end{tabular}

Source: Punjab Education Report, (2010), The Hope PEF Vol: (10) January, 2010 and Vol: (13) 2011.

Table.No.1.4

Evaluation Exercises and Output of Cluster Based Training The following table reflects the improvement of the participants.

\begin{tabular}{llllll} 
S. & & Scores & & & \%(Items) \\
\cline { 3 - 5 } No & Subject & Pre-Test & Post-Test & Difference & Improvement \\
\hline 1 & English & 774 & 1167 & 393 & $34 \%$ \\
2 & Math & 413 & 502 & 89 & $11 \%$ \\
3 & Science & 314 & 561 & 247 & $31 \%$ \\
& Total & 1501 & 2230 & 729 & $23 \%$ \\
\hline
\end{tabular}

Source: Workshop Report of CBT 72 ${ }^{\text {nd }}$ Chakwal (Pakistan) from 13-19 June 2006 Organized by ABES in collaboration with PEF

Table.No.1.5 
Evaluation Exercises and Output of Cluster Based Training

The following table reflects the Workshop Assessment of the participants.

$\mathrm{A}=$ Excellent $\mathrm{B}=$ Good $\mathrm{C}=$ Satisfactory $\mathrm{D}=$ Not satisfactory

English

Science

Mathematics

\begin{tabular}{lllllllll}
\hline $\mathbf{A}$ & $\mathbf{B}$ & $\mathbf{C}$ & $\mathbf{A}$ & $\mathbf{B}$ & $\mathbf{C}$ & $\mathbf{A}$ & $\mathbf{B}$ & $\mathbf{C}$ \\
$51 \%$ & $33 \%$ & $12 \%$ & $62 \%$ & $31 \%$ & $8 \%$ & $62 \%$ & $27 \%$ & $6 \%$ \\
\hline
\end{tabular}

Source: Workshop Report of CBT 72 ${ }^{\text {nd }}$ Chakwal (Pakistan) from 13-19 June 2006 Organized by ABES in collaboration with PEF

\section{School Leadership Development Program (SLDP)}

Considering the school principals' central role and their decisive input in managing the affairs of the schools even to the minutest details, it was realized that many teachers were finding it difficult to incorporate and integrate the newly inducted teaching techniques in their mentoring practices. Out of many associated reasons for this, non-sensitization of school principals was being cited as the main obstacle. Consequently PEF, on the heads' requests, launched Two-day separate training workshop (SLDP Program) in February, 2007 initially for the school principals/heads \& second-in-command precisely focusing on their administrative and pivotal needs.

Through this SLDP module school heads/principals are sensitized on educational management aspects with particular focus on education theories, interactive teaching methods, effective school management and use of pedagogical skills. Each SLDP module is 6 hours event in which 15-20 participants are invited. Each participant is paid honorarium Rs. 150/- per day. The participants are awarded a certificate from PEF also. The services of eminent training organizations are hired that conduct SLDP at a given cost.

Teaching in Clusters by Subject Specialists (TICSS) and Responsibilities of the Subject Specialists

The low cost schools in rural and less affluent urban areas (24 out of 35 Districts of the Punjab) cannot afford qualified teachers of impeccable professional standing due to financial constraints. The subject specialists (in English Language Teaching, Physics, Biology, Chemistry and Mathematics or any newly emerging scientific disciplines) have been recruited, who teach in a cluster of schools. They visit 2-3 schools in a week and teach the students in actual class room theatrics. They are impacting the learning outcomes of the students. Moreover, such subject specialists influence the teaching and communicative practices of the peers and associates.

Subject specialists coordinate with the school to arrange Cluster Based Teachers' training workshops for improvement of content knowledge and pedagogical skills. They work in close cooperation with junior language teachers. They are also playing their roles in capacity building of junior teachers. Consequently the subject specialists are playing a catalytic role in uplifting educational standards and bringing innovations in a number of spheres in schools' milieu regarding teachers' professional development.

\section{Discussion and Conclusions}


The main objective of the study was to analyze the role of PEF in teachers' training in developing professional attitude of school teachers because the teachers are expected to use the best practices and strategies to meet challenge demands of their career. If the teachers are well trained and highly motivated, learning will be enhanced. Therefore it was concluded that teachers' training programs; CBTs and SLDP are more successful in developing overall attitude toward teaching profession. The main points of the CBTs and SLDPs can be concluded as follows:

1. The new teaching methods are adopted instead of traditional methods during training workshops.

2. The training workshops help in enhancement and development of professional competency of teachers instead of contents.

3. The latest teaching techniques and strategies and AV Aids like Lap Top, Multimedia and projectors etc are being used during teachers' training workshops. These modern technologies have increased the rate of learning to a great extent.

4. The workshops are helpful to create the sense of devotion and commitment among teachers.

\section{Recommendations}

Pakistan has lagged behind in educational attainment for the last two decades. An educational emergency needs to be declared. The focus should be on the standards and quality of teaching at schools, rather than quantity in enrollment. Innovative teaching methods, effective teachers' training, revision of curriculums, etc. are the indispensable elements for up lifting the standard of education. Classroom methodology and an improvement in teachers' training are most essential.

Teachers' training programs need reevaluation and reorganization to remove the deficiencies. The trainers/resource persons of teachers' training program needs to re-evaluate their own attitudes toward teaching profession as well as their behavior.

Standardized teachers' training shall be established in those provinces where it has not already been done. Training shall cover a wide range of areas; pedagogy and pedagogical content knowledge, subject content knowledge, testing and assessment practices, monitoring and evaluation and programs to provide to emerging needs like trainings in languages and ICT. Training needs shall be assessed on the basis of research and survey during training programs. Trainings shall emphasize developing the capacity of teachers and school managers for school development plans. Keeping in view the conclusions of the study it is clear that teachers' training programs are successful to some extent in developing professionalism of the teachers. Therefore it is the dire need to bring further improvement. Following recommendations are made here.

- Studies for determining the causes of deterioration in the attitude of teachers are urgently needed so that remedial measures could be adopted to improve the situation

- The trainers of teachers' training programs needs to re-evaluate their own attitudes toward teaching profession because most of them are fresh graduates and have not gone through master training by PEF.

- The selection criteria should be reviewed because the trainers are selected on the basis of 
degrees and test/interview whereas the professional approach is major feature of training of trainers. It should be evaluated through demonstration. So that the aptitude or inclination towards teaching profession of the trainers may be identified.

- The professional approach of the organizations/NGOs should also be observed by the competent authority. It is observed that business minded people are running organizations where the education field needs the professional personnel having education sensitization instead of the trend of money making.

- Mostly the teachers' training clusters are selected on the willing of respective school administration where the majority of the trainees agree for workshop because of honorarium @ Rs. 600 per week. This traditional selection criterion should be changed and the specific and logic based criteria for the selection of trainees should be formulated as the diversified teachers in terms of qualifications and experiences teach at school level. The trainees having almost the same qualification level and experiences should be included in the same cluster.

- The duration of teacher training should be lengthened to develop a favourable attitude of trainees towards teaching profession.

- The fundamental function of teachers' training should be to stimulate learning, to enhance thinking, to develop personality, to develop for self expression, to facilitate self actualization and to extend human potentialities.

- The objectives of the teachers' training should be aimed at the enhancement and development of professional competence of teachers. After training, the teachers should possess competencies such as confidence, command over topic/subject, readiness and motivation for learning, democratic environment of the classroom, questioning techniques, awareness about instructional technology and shifting from theoretical to practical skills.

- The certified trainers should also be trained by the competent and professional experts.

- The Teachers' Training workshops should be organized in far-flung rural areas. The ratio of the workshops is highly greater in urban areas whereas the rural teachers need more professional development.

- Contents in modules prepared by the Organizations/NGOs are not standardized and updated. The PEF should develop a mechanism for the preparation of the modules for each subject.

- Trainers' evaluation report should also be sent to them so that they may judge their performance for further improvement. The prize or/and certificates should be given to the first-class trainers for each subject separately.

- Cluster Based Trainings should be arranged separately for primary, elementary and secondary school teachers due to the diversification in qualification, exposure and experience.

- PEF should publish its reports on annual basis and replicate at the district and provincial level too.

- Seminars and conferences/teleconferences should be organized by the joint venture of PEF and organizations for the awareness of public.

- The real success of qualitative improvement in teachers' training depends upon the sense of purpose, devotion and commitment of teachers who feel proud of teaching profession. 
Training workshops should be frequently arranged to face the supreme challenges which could be met by real sacrifice of teachers in the form of our tradition, not by material gain.

- The trainers should be paid directly through PEF because the Organizations exploit the trainers and don't follow the criteria specified by PEF.

- The certificate should be issued for host school and trainers too at the completion of the training workshop.

\section{Acknowledgements}

We find no words to express our gratitude and profound admiration to thank Raja Muhammad Anwer, Chairman Punjab Education Foundation, Pakistan and Ms Maleeha Batool Director PEF-CPDP program for their cooperation in providing the latest data, helpful comments and suggestions.

\section{Bibliography}

Akiyama, S. (2005). Millennium Development Goals. New Approaches to Development and Changing Sector Issues, 34.

Berry, B. (2001). No Shortcuts to Preparing Good Teachers. Educational Leadership, 58(8), 32-36.

Brookfield, S. (2006). The skillful teacher: On technique, trust, and responsiveness in the classroom: Jossey-Bass Inc Pub.

Chism, N. V. N. (1998). Developing a philosophy of teaching statement. Essays on Teaching Excellence, 9(3), 1-2.

Darling-Hammond, L. (2003). Keeping Good Teachers: Why It Matters, What Leaders Can Do. Educational Leadership, 60, n8.

Government of Pakistan. (1947). First educational conference 1947. Islamabad: Ministry of Education. Government of Pakistan.

Government of Pakistan. (1951). Second educational conference 1951. Islamabad: Ministry of Education. Government of Pakistan.

Government of Pakistan. (1959). National education commission 1959. Islamabad: Ministry of Education. Government of Pakistan.

Government of Pakistan. (1966). Commission on students' problems and welfare 1966. Islamabad:

Ministry of Education. Government of Pakistan.

Government of Pakistan. (1969). The new education policy 1969-70. Islamabad: Ministry of $\backslash$ Education.

Government of Pakistan.

Government of Pakistan. (1972). The education policy 1972. Islamabad: Ministry of Education.

Government of Pakistan.

Government of Pakistan. (1979). National education policy and implementation program 1979.

Islamabad: Ministry of Education. Government of Pakistan.

Government of Pakistan. (1992). National education policy 1992. Islamabad: Ministry of Education. 
Government of Pakistan.

Government of Pakistan. (1998). National education policy 1998-2010. Islamabad: Ministry of Education. Government of Pakistan.

Government of Pakistan. (2000). Knowledge and skills for life, first results from PISA 2000 Organization

Of Economic Co-operation and Development (OECD).

Government of Pakistan. (2005). Teachers' matters, attracting, developing and retaining effective

Teachers, OECD: 2005.

Government of Pakistan. (2007a). Education in Pakistan, a white paper revised document to debate

And finalize the national education policy, (draft document) Islamabad: Ministry of

Education. Government of Pakistan. p-84-85

Government of Pakistan. (2007b). National curriculum for early childhood education. Ministry of

Education. Islamabad. Pakistan.

Government of Pakistan. (2009, Nov). National educational policy 2009. Ministry of Education

Islamabad. Government of Pakistan. p-32,34,35.

Government of the Punjab, (2006). A guide for district teacher educators. Directorate of Staff Development. Lahore.

Hussain, S. (2004). Effectiveness of teacher training in developing professional attitude of prospective secondary school teachers. University of Arid Agriculture, Rawalpindi.

Joyce, B., \& Weil, M. (1986). Models of teaching. Englewood Cliffs, NJ.

Kabeer, N. (2003). Gender Mainstreaming in Poverty Eradication and the Millennium Development Goals: A handbook for policy-makers and other stakeholders: VL.

Ki-Moon, B. (2007). Children and the Millennium Development Goals. Progress Towards a World Fit for Children UNICEF, New York.

Knowles, M. S. (1984). Andragogy in action: Jossey-Bass San Francisco.

Littlefield, E., Morduch, J., \& Hashemi, S. (2003). Is microfinance an effective strategy to reach the Millennium Development Goals? Focus Note, 24(2003), 1-11.

Memon, G. R. (2007). Education in Pakistan: The key issues, problems and the new challenges. Journal of Management and Social Sciences, 3(1), 47-55.

Nunan, D. (1991). Language teaching methodology: A textbook for teachers (Vol. 128): Prentice Hall United Kingdom.

O’Sullivan, C. (2005). Path dependent option pricing under Lévy processes EFA 2005 Moscow Meetings Paper.

Prince, C. (2002). The challenge of attracting good teachers and principals to struggling schools. Alexandria, VA: American Association for Supervision and Curriculum Development. Retrieved on September, 16, 2007.

Punjab Education Report, (2010), The Hope PEF Vol: (10) January, 2010 and Vol: (13) 2011

Robertson, D. L. (1996). Educational Helping Relationship. Adult Education Quarterly, 47(1), 41-53. 


\section{Macrothink

Saphier, J., \& Gower, R. (1997a). The skillful teacher . Carlisle, MA: Research for Better Teaching: Inc.

Saphier, J., \& Gower, R. (1997b). The skillful teacher: Building your teaching skills. Carlisle, MA: Research for Better Teaching: Inc.

Saphier, J., \& Gower, R. R. (1997). The skillful teacher: Building your teaching skills: Research for Better Teaching Acton, Mass.

Sargent, B. (2003). Finding Good Teachers--And Keeping Them. Educational Leadership, 60(8), 44-47.

Shah, D. (2003). Decentralization in the education system of Pakistan: Policies and strategies. Paper for Academy of Educational Planning and Management.

Stone, M., Horejs, J., \& Lomas, A. (1997). Commonalities and differences in teacher leadership at the elementary, middle, and high school levels. Action in Teacher Education, 19(3), 49-64.

Tennant, M., \& Pogson, P. (1995). Learning and change in the adult years: A developmental perspective: Jossey-Bass San Francisco.

Ungurean, C. (2005). MILLENNIUM DEVELOPMENT GOALS. Silvia Gabriela Scîntee and Adriana Galan, 142.

Wilson, J. H. (1969). The "new" science teachers are asking more and better questions. Journal of Research in Science Teaching, 6(1), 49-53. 